\title{
The impacts of precursor reduction and meteorology on ground-level ozone in the Greater Toronto Area
}

\author{
S. C. Pugliese ${ }^{1}$, J. G. Murphy ${ }^{1}$, J. A. Geddes ${ }^{1, *}$, and J. M. Wang ${ }^{1, * *}$ \\ ${ }^{1}$ University of Toronto, Department of Chemistry, 80 St. George St, Toronto, ON, M5S 3H6, Canada \\ *now at: Dalhousie University, Department of Physics and Atmospheric Science, P.O. Box 15000, \\ Halifax, NS, B3H 4R2, Canada \\ ** now at: University of Toronto, Department of Chemical Engineering and Applied Science, 200 College St. Toronto, \\ ON, M5S 3E5, Canada
}

Correspondence to: J. G. Murphy (murphy@chem.utoronto.ca)

Received: 10 March 2014 - Published in Atmos. Chem. Phys. Discuss.: 22 April 2014

Revised: 8 July 2014 - Accepted: 11 July 2014 - Published: 15 August 2014

\begin{abstract}
Tropospheric ozone $\left(\mathrm{O}_{3}\right)$ is a major component of photochemical smog and is a known human health hazard, as well as a damaging factor for vegetation. Its precursor compounds, nitrogen oxides $\left(\mathrm{NO}_{\mathrm{x}}\right)$ and volatile organic compounds (VOCs), have a variety of anthropogenic and biogenic sources and exhibit non-linear effects on ozone production. As an update to previous studies on ground-level ozone in the Greater Toronto Area (GTA), we present an analysis of $\mathrm{NO}_{2}$, VOC and $\mathrm{O}_{3}$ data from federal and provincial governmental monitoring sites in the GTA from 2000 to 2012. We show that, over the study period, summertime $24 \mathrm{~h}$ VOC reactivity and $\mathrm{NO}_{2}$ midday (11:00-15:00) concentrations at all sites decreased significantly; since 2000, all sites experienced a decrease in $\mathrm{NO}_{2}$ of $28-62 \%$ and in measured VOC reactivity of at least 53-71\%. Comparing 20022003 to 2011-2012, the summed reactivity of $\mathrm{OH}$ towards $\mathrm{NO}_{2}$ and a suite of measured VOCs decreased from 8.6 to $4.6 \mathrm{~s}^{-1}$. Ratios of reactive VOC pairs indicate that the effective $\mathrm{OH}$ concentration experienced by primary pollutants in the GTA has increased significantly over the study period. Despite the continuous decrease in precursor levels, ozone concentrations are not following the same pattern at all stations; it was found that the Canada-wide Standard for ozone continues to be exceeded at all monitoring stations. Additionally, while the years 2008-2011 had consistently lower ozone levels than previous years, 2012 experienced one of the highest recorded summertime ozone concentrations and a large number of smog episodes. We demonstrate that these high ozone observations in 2012 may be a result of the num-
\end{abstract}

ber of days with high solar radiation, the number of stagnant periods and the transport of high ozone levels from upwind regions.

\section{Introduction}

At ground level, $\mathrm{O}_{3}$ is toxic to both humans and vegetation as a result of its ability to oxidize biological tissues (Bell et al., 2005). It is well documented that human exposure to ozone leads to respiratory problems and an increased risk of hospital admissions (Bell et al., 2004) and, as a result of these and reduced agricultural yields, yearly economic losses attributed to ozone and fine particulate-matter pollution are as high as CAD 9.6 billion in the province of Ontario alone (MOE, 2005). In Toronto, ground-level ozone is responsible for 13-29\% of the incidences of premature mortality and hospitalizations associated with air pollution (with $\mathrm{PM}_{2.5}$ and $\mathrm{NO}_{2}$ being responsible for the remainder) (Toronto Public Health, 2014). In response to this, many governments and regulatory agencies have imposed air quality standards to protect the population against exposure to $\mathrm{O}_{3}$ and other pollutants. In 2000, Canada adopted a Canada-wide Standard (CWS) for ozone, which states that the 3-year average of the 4th-highest daily maximum $8 \mathrm{~h}$ average should not exceed 65 ppb. In 2007, the City of Toronto, Canada's largest urban area, made a commitment in its Climate Change Clean Air and Sustainable Energy Action Plan to reduce emissions of local smog-causing pollutants to $20 \%$ below 2004 levels by 
2012 (City of Toronto, 2007). This regulation is happening in the context of regional-scale initiatives to control emissions of ozone precursor compounds, such as the "Drive Clean" vehicle test program in Ontario (MOE, 2013) and the phasing out of coal-fired, power-generating stations (Bradley, 2013). However, as a secondary pollutant, $\mathrm{O}_{3}$ has proven to be one of the most difficult pollutants to bring into compliance with air-quality standards. Its precursor compounds, volatile organic compounds (VOCs) and $\mathrm{NO}_{\mathrm{x}}\left(\mathrm{NO}_{\mathrm{x}}=\mathrm{NO}+\mathrm{NO}_{2}\right)$, are emitted by a variety of anthropogenic and biogenic sources, the former dominated by combustion, fuel evaporation and chemical manufacturing, while the latter is dominated by transportation and electricity generation (ICF, 2007). These primary pollutants interact in the presence of sunlight (forming a condition known as photochemical smog), producing ground-level ozone and other secondary pollutants. However, the production rate of ozone depends on precursor concentrations in a non-linear fashion. Previous studies of $\mathrm{O}_{3}$ concentrations have indicated considerable variability from day to day and from year to year, not only as a result of changes in precursor emissions, but also of meteorology (AgudeloCastaneda et al., 2013; Figueiredo et al., 2013; Jacob et al., 1993; Pekey and Ozaslan, 2013; Psiloglou et al., 2013). Empirical and model studies have shown very strong positive correlations between $\mathrm{O}_{3}$ production and temperature, and weaker correlations of ozone accumulation with wind speed and direction, pressure, cloud cover and humidity (BaertschRitter et al., 2004; Camalier et al., 2007; Dawson et al., 2007; Jacob et al., 1993). All of these meteorological parameters affect the photochemistry occurring in the troposphere and, consequently, the rate of $\mathrm{O}_{3}$ production.

In the troposphere in the summertime, ozone is produced rapidly via the photochemical oxidation of VOCs in the presence of $\mathrm{NO}_{\mathrm{x}}$. During the day, the interconversion of $\mathrm{NO}$ and $\mathrm{NO}_{2}$ occurs with $\mathrm{O}_{3}$ on the order of minutes (following Reactions R1a-R2).

$\mathrm{NO}_{2}+h v \rightarrow \mathrm{NO}+\mathrm{O}$

$\mathrm{O}+\mathrm{O}_{2}+\mathrm{M} \rightarrow \mathrm{O}_{3}+\mathrm{M}$

$\mathrm{NO}+\mathrm{O}_{3} \rightarrow \mathrm{NO}_{2}+\mathrm{O}_{2}$

This chemistry produces a null cycle with respect to $\mathrm{NO}_{\mathrm{x}}$ and $\mathrm{O}_{3}$; there is no net production or consumption of either. However, in the presence of VOCs, net production of $\mathrm{O}_{3}$ can occur following oxidation of a hydrocarbon ( $\mathrm{RH}$, where $\mathrm{R}$ is any organic group) by the hydroxyl radical, $\mathrm{OH}$, producing an organic peroxy radical, $\mathrm{RO}_{2}$ (Reaction $\mathrm{R} 3$ ). The organic peroxy radical can then further react with $\mathrm{NO}$ to form $\mathrm{NO}_{2}$ and an organic alkoxy radical, RO (Reaction R4).

$\mathrm{OH}+\mathrm{RH}+\mathrm{O}_{2} \rightarrow \mathrm{H}_{2} \mathrm{O}+\mathrm{RO}_{2}$

$\mathrm{RO}_{2}+\mathrm{NO} \rightarrow \mathrm{RO}+\mathrm{NO}_{2}$

The $\mathrm{NO}_{2}$ formed in Reaction (R4) can photolyze during the daytime to regenerate $\mathrm{NO}$ and an oxygen atom (Reaction R1a), which can then recombine with an oxygen molecule to form $\mathrm{O}_{3}$ (Reaction R1b). There are several possible fates for the RO radical: it may react with $\mathrm{O}_{2}$, thermally decompose or isomerize. Typically, carbonyl compounds and an $\mathrm{HO}_{2}$ radical are produced (Reaction R5), and the net reaction (Reactions R1-R6) results in the formation of two ozone molecules (Reaction R7).

$$
\begin{aligned}
& \mathrm{RO}+\mathrm{O}_{2} \rightarrow \mathrm{R}^{\prime} \mathrm{CHO}+\mathrm{HO}_{2} \\
& \mathrm{HO}_{2}+\mathrm{NO} \rightarrow \mathrm{OH}+\mathrm{NO}_{2} \\
& \mathrm{RH}+4 \mathrm{O}_{2} \rightarrow \mathrm{R}^{\prime} \mathrm{CHO}+2 \mathrm{O}_{3}+\mathrm{H}_{2} \mathrm{O}
\end{aligned}
$$

In this study, the total oxidant, $\mathrm{O}_{\mathrm{x}}$, is defined as the sum of $\mathrm{NO}_{2}$ and $\mathrm{O}_{3}\left(\left[\mathrm{O}_{\mathrm{x}}\right]=\left[\mathrm{NO}_{2}\right]+\left[\mathrm{O}_{3}\right]\right)$ and $\mathrm{O}_{\mathrm{x}}$ can therefore only increase in the presence of VOCs when $\mathrm{O}_{3}$ is formed via Reactions (R3)-(R4) followed by Reaction (R1a)-(R1b), whereas it is conserved when $\mathrm{O}_{3}$ is formed via Reaction (R2) followed by Reaction (R1a)-(R1b). It is often advantageous to analyze $\mathrm{O}_{x}$ over $\mathrm{O}_{3}$ because it is a better measure of the photochemical production of ozone as it more closely represents the total oxidant; it is not affected by the titration of $\mathrm{O}_{3}$ with NO.

This catalytic ozone production chain is terminated by the loss of $\mathrm{HO}_{\mathrm{x}}$ radicals $\left(\mathrm{HO}_{\mathrm{x}}=\mathrm{OH}+\mathrm{RO}+\mathrm{HO}_{2}+\mathrm{RO}_{2}\right)$, which can occur through multiple pathways. In an environment with a low $\mathrm{NO}_{\mathrm{x}}$ : VOC ratio, such as a rural location, peroxy radicals may undergo a self-reaction instead of reacting with NO to produce peroxides or other oxygenated compounds (Reaction R8).

$\mathrm{RO}_{2}+\mathrm{R}^{\prime} \mathrm{O}_{2} \rightarrow \mathrm{ROOR}^{\prime}+\mathrm{O}_{2}$

Under this pathway, the addition of $\mathrm{NO}_{\mathrm{x}}$ increases $\mathrm{O}_{3}$ production by enhancing the rate of Reaction (R6), while addition of VOCs has a negligible effect as they can react with nearly every $\mathrm{OH}$ produced. Thus, $\mathrm{O}_{3}$ production increases linearly with increasing $\mathrm{NO}_{\mathrm{x}}$, and it is less sensitive to VOC reactivity. However, in an environment with a high $\mathrm{NO}_{\mathrm{x}}$ : VOC ratio, the dominant sink for $\mathrm{HO}_{\mathrm{x}}$ is the oxidation of $\mathrm{NO}_{2}$ by $\mathrm{OH}$, forming nitric acid (Reaction $\mathrm{R} 9$ ).

$\mathrm{NO}_{2}+\mathrm{OH}+\mathrm{M} \rightarrow \mathrm{HNO}_{3}+\mathrm{M}$

Under this pathway, the addition of $\mathrm{NO}_{\mathrm{x}}$ decreases $\mathrm{O}_{3}$ production because $\mathrm{NO}_{2}$ can compete with VOCs for $\mathrm{OH}$. Thus, $\mathrm{O}_{3}$ production becomes inversely proportional to $\mathrm{NO}_{\mathrm{x}}$ levels and more sensitive to VOC reactivity.

Alternatively, chain termination can also occur following the reaction between peroxy radicals and $\mathrm{NO}_{\mathrm{x}}$, forming peroxy acyl nitrates $\left(\mathrm{PNs}=\mathrm{RC}(\mathrm{O}) \mathrm{O}_{2} \mathrm{NO}_{2}\right.$, Reaction R10) or alkyl nitrates (ANs $=\mathrm{RONO}_{2}$, Reaction R11) (Farmer et al., 2011). PNs serve as a temporary reservoir for $\mathrm{NO}_{\mathrm{x}}$ and suppress $\mathrm{O}_{3}$ formation in the near field but transport and release $\mathrm{NO}_{\mathrm{x}}$ in the far field, extending the formation of ozone (Perring et al., 2010). Conversely, ANs are considered permanent sinks for $\mathrm{NO}_{\mathrm{x}}$, affecting only local $\mathrm{O}_{3}$ production (Perring et 
al., 2010).

$\mathrm{RC}(\mathrm{O}) \mathrm{O}_{2}+\mathrm{NO}_{2} \leftrightarrow \mathrm{RC}(\mathrm{O}) \mathrm{O}_{2} \mathrm{NO}_{2}$

$\mathrm{RO}_{2}+\mathrm{NO}+\mathrm{M} \rightarrow \mathrm{RONO}_{2}+\mathrm{M}$

This analysis extends an earlier study by Geddes et al. (2009) that demonstrated how summertime VOC reactivity and ambient concentrations of $\mathrm{NO}_{2}$ decreased from 2000 to 2007 by up to $40 \%$ in the Greater Toronto Area (GTA), but no significant ozone reductions were observed. It was argued that decreased titration may have contributed to higher $\mathrm{O}_{3}$ mixing ratios, and that air transport from the southwest may have contributed to early-morning $\mathrm{O}_{\mathrm{x}}$ levels (Geddes et al., 2009). In this work, we discuss how GTA ozone levels now appear to be responding to decreases in precursor compounds, as reductions are observed from 2000 to 2012 . We also identify that, in the short-term, 2012 marked one of the highest years in GTA ozone during the study period. We discuss the strong link between ozone levels and local meteorology, particularly solar radiation as well as the degree of regional air transport, to help explain this occurrence. We also examine changes in $\mathrm{OH}$ reactivity and abundance over the study period.

\section{Methods}

\subsection{Study region and data collection}

The City of Toronto $\left(43^{\circ} 40^{\prime} \mathrm{N}, 79^{\circ} 23^{\prime} \mathrm{W}\right)$ is located in Southern Ontario on the northwest shore of Lake Ontario, and is the largest urban area in Canada, as well as one of its most densely populated regions (945.4 persons per square kilometer) (Statistics Canada, 2012). The GTA comprises four municipalities - Halton, Durham, Peel and York - which together have a population exceeding 6 million (Statistics Canada, 2012). During the summer, the GTA is affected by warm southerly and southwesterly air transport, as well as local land-lake breezes from Lake Ontario (Makar et al., 2010). The city's $\mathrm{NO}_{\mathrm{x}}$ emissions are dominated by the transportation sector $(63 \%)$, with diesel trucks accounting for a disproportionately large percentage (36\%) (ICF, 2007). When solely considering the emissions made directly in the city (neglecting those from energy generated outside the City of Toronto, required to meet the city's needs), transportation accounts for an even larger amount $(73 \%)$ of total $\mathrm{NO}_{\mathrm{x}}$ emissions, with diesel vehicles accounting for $45 \%$ of this total (ICF, 2007). In Toronto, anthropogenic VOC emissions come almost exclusively from gasoline powered cars and light trucks (ICF, 2007). Despite efforts made by the city to reduce emissions of smog precursors, the GTA issues frequent smog advisories each year, historically ranging from one advisory in 2011 to 14 advisories in 2005 (MOE, 2014).

$\mathrm{NO}_{\mathrm{x}}, \mathrm{O}_{3}$ and VOC data used in this study were obtained from the National Air Pollution Surveillance (NAPS) network. For the $\mathrm{NO}_{\mathrm{x}}$ and $\mathrm{O}_{3}$ analyses, eight sites across the GTA were selected, four of which are considered urban (Downtown2, Toronto North, Toronto East, and Toronto West2) and the remaining four are considered suburban (Oshawa, Brampton2, Newmarket and Oakville) (see Fig. 1). Hourly data for both $\mathrm{NO}_{\mathrm{x}}$ and $\mathrm{O}_{3}$ are available from the year 2000 onwards and are publically accessible at http: //www.airqualityontario.com. At all stations, $\mathrm{NO}_{2}$ and $\mathrm{O}_{3}$ measurements were made by automated continuous chemiluminescent and UV-absorption analyzers respectively, with sampling heights varying from 4 to $12 \mathrm{~m}$ above ground level. All data sets were complete (less than $\sim 24$ individual hours per summer not having a measurement), and any missing data were treated as undefined values. During the same study period, VOC data were obtained from Environment Canada for four stations across the GTA (Downtown1, sampling from 2002 to the present; Toronto West1, sampling from 2000 to 2010; Junction, sampling from 2000 to 2005; and Brampton1, sampling from 2001 to 2010), also shown in Fig. 1. At all stations, $24 \mathrm{~h}$ samples were collected once every 6 days in evacuated electropolished stainless-steel canisters and sent to Environment Canada (Ottawa, Ontario) for analysis by gas chromatography/flame ionization detection (for $\mathrm{C}_{2}$ hydrocarbons) and gas chromatography/mass spectrometric detection (for $\mathrm{C}_{3}-\mathrm{C}_{12}$ hydrocarbons) as described in Wang et al. (2005). In 2000, 2001, 2004 and 2005, carbonyl compounds were automatically sampled at the Junction site using 2,4-dinitrophenylhydrazine coated silica Sep-Pak cartridges for $24 \mathrm{~h}$, then separated and identified using HPLC and UV DAD detection at $365 \mathrm{~nm}$ (Wang et al., 2005). Additional VOC sampling was carried out in 2011 at the Downtown Toronto sampling site (Downtown1) using an automatic sampler (model 910PC, XonTech Inc., VanNuys, CA) with eight consecutive $3 \mathrm{~h}$ samples collected every $24 \mathrm{~h}$ over 5 days during late summer (27 August, 31 August, 2 September, 9 September and 12 September). Samples were analyzed for both non-polar and polar VOCs using GC techniques described in Wang et al. (2005).

\section{$2.2 \mathrm{O}_{3}, \mathrm{NO}_{\mathrm{x}}$ and $\mathrm{VOC}$ analyses}

Daily $8 \mathrm{~h}$ maximum $\mathrm{O}_{3}$ and $\mathrm{O}_{\mathrm{x}}$ were calculated for each site throughout the 13-year study period; this was done by considering each hour in a particular day (00:00-23:00) and averaging the ozone (or $\mathrm{O}_{\mathrm{x}}$ ) concentration during a time period that includes $3 \mathrm{~h}$ prior to and $4 \mathrm{~h}$ following that time (creating a total of 24 points in $8 \mathrm{~h}$ concentrations). The largest value was reported as the maximum $8 \mathrm{~h}$ average for the given day, assigned using the fourth hour. Any missing data were treated as undefined values. The $\mathrm{O}_{3}$ diurnal cycle was examined and it was determined that the most photochemically relevant hours for $\mathrm{O}_{3}$ production were between 11:00 and 15:00 (EST; solar noon is approximately 12:30 EST during the summer). Therefore, $\mathrm{NO}_{2}$ hourly data were averaged during this time period (hereafter referred to as the " $\mathrm{NO}_{2}$ midday average"). Using this data, annual summer averages were 


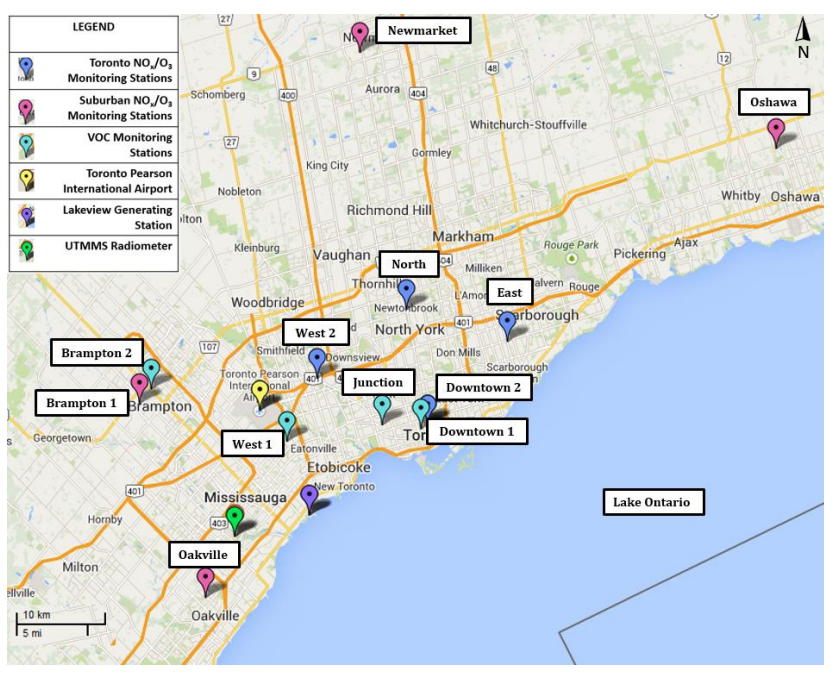

Figure 1. Monitoring stations in the Greater Toronto Area used for the collection of $\mathrm{NO}_{\mathrm{x}}$ and $\mathrm{O}_{3}$ data (blue and pink markers), VOC data (aqua markers) and meteorological data (yellow and green markers).

calculated (where summer is defined as May to September inclusive) as it is the most photochemically relevant time of year.

VOC reactivity was calculated as the product of the VOC's number density and its rate constant against the hydroxyl radical (Atkinson, 1997; Seinfeld and Pandis, 2006). Summer annual averages for total VOC reactivity were calculated as the sum of all VOC reactivity $\left(\sum k_{i}\left[\mathrm{VOC}_{i}\right]\right)$ in units of inverse seconds. The influences of biogenic, anthropogenic and oxygenated VOCs (OVOCs) were distinguished by identifying the sum of isoprene (and terpenes), cymene, pinene, limonene and camphene as biogenic VOCs, the sum of formaldehyde, acetaldehyde, acrolein, acetone, and propionaldehyde as OVOCs (applicable for only the Junction site) and the sum of the remaining 40 VOCs as anthropogenic. Although the NAPS network monitors for a larger suite of VOC compounds, we chose the 50 compounds that were consistently measured across all sites and years to be included in this analysis to remove incorrect interpretation of interannual and inter-spatial variability in the data (removed compounds generally contributed less than $\sim 9 \%$ of total VOC reactivity for a summer period).

For all compounds, annual trends were calculated by a linear regression analysis and their significance measured by their $p$ values. $p$ values were calculated from a standard $t$ test where the null hypothesis being tested is that the slope of the regression line is equal to zero. Annual trends with $p$ values $<0.05$ are considered significant.

\subsection{Meteorological analyses}

Hourly meteorological data were continuously collected throughout the study period at Toronto's Pearson Interna- tional Airport (Fig. 1), and these data were accessed from National Climate Data and Information Archive operated by Environment Canada. Maximum daily temperatures were calculated for each summer, and the number of days on which this maximum exceeded $30^{\circ} \mathrm{C}$ was recorded. From this same archive, hourly wind speed and direction were obtained and net wind vectors were calculated for a $12 \mathrm{~h}$ period prior to each afternoon (00:00 to 12:00) to assess air-mass history. This technique was adopted from Geddes et al. (2009), where the magnitude of the $x$ and $y$ component of the hourly wind vector was summed and used to calculate the resultant vector by trigonometry. The result is a single vector that represents the strength and the net direction of air transport for each day. This approach was chosen because the location of the GTA on the northern shore of Lake Ontario leads to frequent local lake-breeze flow patterns that are not generally wellrepresented in back trajectory analyses (Sills et al., 2011).

To assess the level of photochemical activity occurring on each day, the amount of incoming solar radiation was analyzed. Data were collected using both a net radiometer (CNR1, Campbell Scientific Corp.) and a pyranometer (CMP 11, Kipp and Zonen B.V.) operated at the University of Toronto Mississauga Department of Geography's Meteorological Station (UTMMS) (Fig. 1). From the hourly data, midday (11:00 to 15:00) solar radiation averages were calculated in $\mathrm{W} \mathrm{m}^{-2}$.

\section{Results and discussion}

\subsection{Long term precursors and $\mathrm{O}_{3}$ levels (2000-2012)}

Annual summer midday averages of daily $\mathrm{NO}_{2}$ are shown in Fig. 2a and b, demonstrating that an overall decrease is present throughout the 13-year study period (2000-2012). The urban sites have the steepest slopes, between -0.64 and -0.92 ppbyear $^{-1}(p<0.01)$, while the suburban sites also have decreasing trends of -0.20 to -0.55 ppb year $^{-1}$ $(p<0.05)$. Overall, throughout the 13-year study period, urban sites experienced an average decrease of $-6.4 \%$ per year (with Toronto Downtown2 experiencing the largest decreases at $-6.9 \%$ per year), while the suburban sites experienced an average decrease of $-5.8 \%$ per year (with Brampton2 experiencing the largest decreases at $-7.2 \%$ per year). The most urban station (Downtown2), and that closest to a major highway (West2), continues to report the highest $\mathrm{NO}_{2}$ levels of all the monitoring stations. Furthermore, the stations furthest removed from the urban center and major highways, Newmarket and Oakville, report the lowest $\mathrm{NO}_{2}$ levels. From 2000 to 2010, the number of registered vehicles in Ontario has increased from approximately 8.6 to 10.6 million (Statistics Canada, 2011) and the decrease in $\mathrm{NO}_{2}$ levels is therefore likely related to improvements in vehicle catalyst technology or the phasing out of older, less efficient vehicles (MOE, 2013). Other factors may include the closure of the Lakeview 


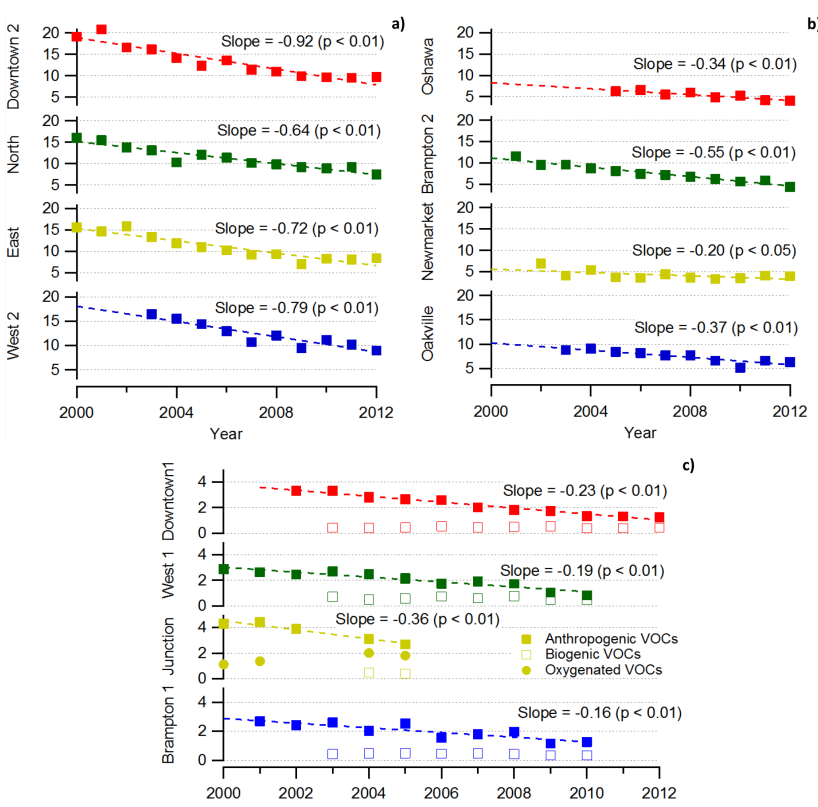

Figure 2. Annual summer midday $\mathrm{NO}_{2}$ concentrations (ppb) in GTA urban (a) and suburban (b) areas; slopes in ppb year ${ }^{-1}$. Annual summer VOC reactivity $\left(\mathrm{s}^{-1}\right)(\mathbf{c})$; slopes in $\mathrm{s}^{-1}$ year ${ }^{-1}$.

Generating Station (Fig. 1) within the GTA in $2005\left(\mathrm{NO}_{2}\right.$ emissions in 2004 were 5000 tonnes), as a part of Ontario's phasing out of coal-fired, power-generating stations (Bradley, 2013), and the large reduction of emissions from the Nanticoke Generating Station, located less than $100 \mathrm{~km}$ southwest of the GTA $\left(\mathrm{NO}_{2}\right.$ emissions decreased from 38000 to 3000 tonnes between 2002 and 2012).

A similar decreasing trend is apparent for anthropogenic VOCs in the GTA. Annual summer averages of VOC reactivity are shown in Fig. 2c and a steadily decreasing trend for anthropogenic VOCs is apparent across all sites. Monitoring at Junction stopped in 2005 and at West1 and Brampton1 in 2011. Therefore, only Downtown1 data are available for 2011 and 2012. All sites have statistically significant declining slopes between -0.16 and $-0.23 \mathrm{~s}^{-1}$ year $^{-1}(p<0.01)$ and an average overall decrease of $-9.3 \%$ per year (excluding Junction site), with the Brampton1 site experiencing the largest decrease of $-11.5 \%$ per year. OVOC reactivity shows a small increasing trend at the Junction site. However, with monitoring having stopped in 2005, no significant conclusions can be drawn. VOC reactivity from biogenic sources shows no apparent trend across the study period. It is clear that, at all sites, VOC reactivity from anthropogenic emissions is approaching the reactivity from biogenic emissions, particularly at the West 1 site.

Figure 3 shows annual summer daily $8 \mathrm{~h}$ maximum $\mathrm{O}_{3}$ and $\mathrm{O}_{\mathrm{x}}$ for the GTA. Following the reductions of both its precursor compounds, $\mathrm{O}_{3}$ and $\mathrm{O}_{\mathrm{x}}$ levels have also generally decreased over the study period. Linear regression analyses show that the eight sites have negative slopes for $\mathrm{O}_{3}$, ranging
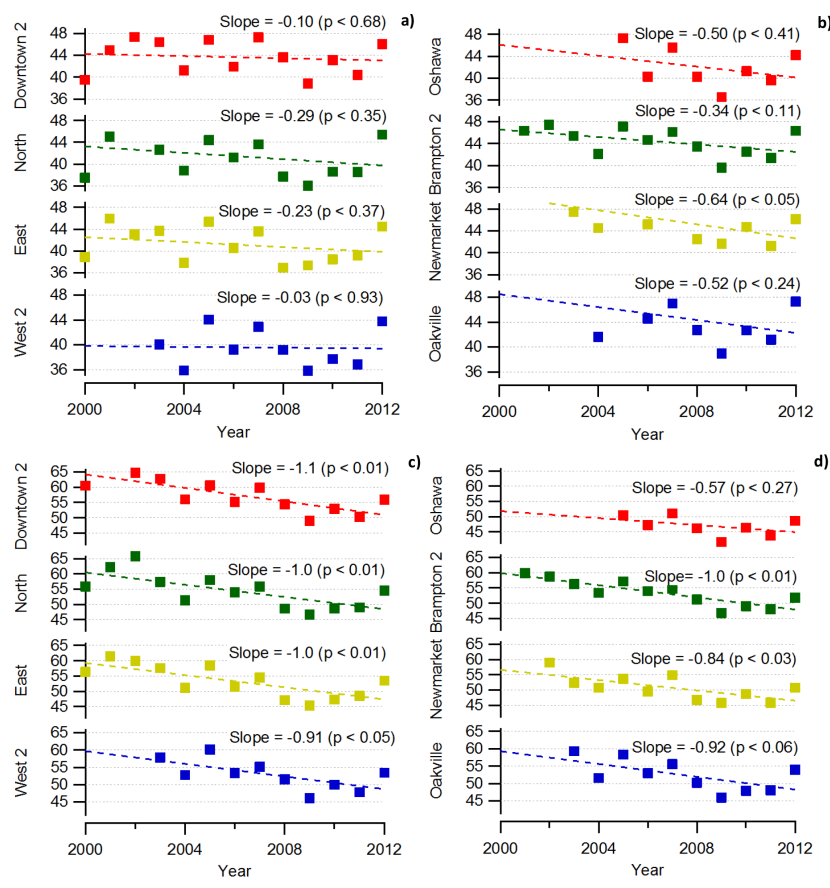

Figure 3. Annual summer average maximum $8 \mathrm{~h} \mathrm{O}_{3}-$ (a) and (b) and $\mathrm{O}_{\mathrm{x}}-(\mathbf{c})$ and (d) - concentrations ( $\mathrm{ppb}$ ) for Toronto urban and suburban areas; slopes in ppb year $^{-1}$.

between -0.03 and -0.29 ppb year $^{-1}$ at the urban stations and -0.34 and -0.64 ppb year $^{-1}$ at the suburban stations, although decreases are not statistically significant (with the exception of Newmarket). Over the entire study period, decreases in $\mathrm{O}_{3}$ of $-0.4 \%$ per year occurred in the urban stations and $-1.1 \%$ per year at the suburban stations. Analyses also show that the eight sites also have negative slopes for $\mathrm{O}_{\mathrm{x}}$, ranging between -0.91 and $-1.1 \mathrm{ppb}$ year $^{-1}$ at the urban stations and -0.57 and -1.0 ppb year $^{-1}$ at the suburban stations, most of which are statistically significant (with the exception of Oshawa and Oakville, which are both missing data at the beginning of the study period). Over the entire study period, decreases in $\mathrm{O}_{\mathrm{x}}$ of $-1.8 \%$ per year occurred in the urban stations and $-1.6 \%$ per year at the suburban stations. If 2012 data is removed from the figures, the slopes for $\mathrm{O}_{\mathrm{x}}$ become significant $(p<0.01)$ at all sites, except for Oshawa which has only been monitoring since 2005 ( $p<0.07)$. While these decreases are likely following the reduction of ozone precursor compounds, other studies have found that changes in background concentrations are responsible for decreases at some monitoring stations (such as Whiteface Mountain, New York, Oltmans et al., 2013), and therefore, this cannot be ruled out as a possible influence to the decreasing trends reported here. 


\section{$3.2 \mathrm{O}_{3}$ levels from 2008 to 2012}

While, over the entire study period, $\mathrm{O}_{3}$ levels in GTA have decreased, the same trend is not observed from 2008 onwards. Figure $3 \mathrm{a}$ and $\mathrm{b}$ show that, at all monitored sites, $\mathrm{O}_{3}$ levels in the GTA were consistently lower between 2008 and 2011 than between 2000 and 2007. However, the measured average summer daily maximum $8 \mathrm{~h} \mathrm{O}_{3}$ in 2012 was significantly higher than that of the previous four years (an increase of 5-7 ppb). The data presented above demonstrate that $\mathrm{NO}_{2}$ levels have not significantly changed from 2011 to 2012 (the largest change was a decrease of $1.7 \mathrm{ppb}$ at the Toronto North site). Additionally, results show that VOC reactivity decreased from 2011 to 2012. Therefore, the 2012 $\mathrm{O}_{3}$ increase cannot be explained as a result of a change in either of the precursor compounds. Alternatively, this variability in $\mathrm{O}_{3}$ may be explained by meteorological influences, which is explored in the following section.

\subsection{Meteorological influences on $\mathrm{O}_{3}$}

Previous studies have provided evidence of a correlation existing between ozone levels and meteorological conditions, such as wind direction and speed, temperature and relative humidity (Agudelo-Castaneda et al., 2013; Figueiredo et al., 2013; Pekey and Ozaslan, 2013; Psiloglou et al., 2013). Specifically, Jacob et al. (1993) discuss the significant dependence of $\mathrm{O}_{3}$ concentrations on temperature, indicating that, at higher temperatures, local $\mathrm{O}_{3}$ production is maximized as a result of the suppression of radicals being stored as peroxyacetylnitrate (PAN). Higher temperatures may also result in enhanced local production of $\mathrm{O}_{3}$ by increasing $\mathrm{HO}_{x}$ production or increasing local biogenic or fugitive anthropogenic (such as the evaporation of oil and/or gas) VOC emissions. Figure 4 displays the number of days each year on which the Toronto Downtown 2 station $8 \mathrm{~h} \mathrm{O}_{3}$ average exceeded $65 \mathrm{ppb}$, the number of days which experienced temperatures exceeding $30^{\circ} \mathrm{C}$, as well as the design value (the fourth highest $8 \mathrm{~h}$ $\mathrm{O}_{3}$ measurement annually, averaged over three consecutive years, Environment Canada, 2013) for that year. A relationship between ozone exceedances and high temperatures is clear during the 2000-2009 period, but less clear from 2010 to 2012. Although 2012 had a large increase in the number of days exceeding the $\mathrm{O}_{3}$ standard, it did not have significantly more days experiencing warmer temperatures compared to 2010 or 2011. This analysis was completed for the other seven stations and the same conclusions are drawn. Therefore, based on this data, the warm temperatures experienced in the summer of 2012 did not play the dominant role in the $\mathrm{O}_{3}$ increase observed.

High temperatures in the GTA are often associated with warm southerly flow, and it is therefore possible that the correlation between $\mathrm{O}_{3}$ and temperature is driven by air transport from upwind regions. As described in the "Methods" section, net wind vectors for each summer day from midnight

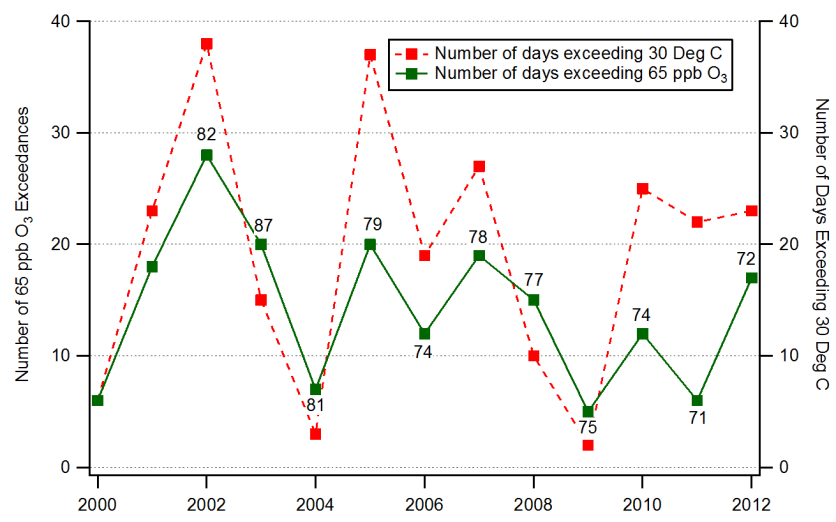

Figure 4. The number of days exceeding $65 \mathrm{ppb}_{3}$ Canada-wide Standard (green) and the number of days exceeding $30^{\circ} \mathrm{C}$ (red) at the Toronto Downtown 2 station. The number above each marker is the design value for that year.

to noon were determined. Following Geddes et al. (2009), we defined days on which the wind speed and direction resulted in a net movement of $>120 \mathrm{~km}$ from the south and southwest $\left(135-270^{\circ}\right)$ as days influenced by "west to south-east flow (W-SE)"; days on which the net wind speed and direction resulted in a net movement of $>120 \mathrm{~km}$ from the north (270$45^{\circ}$ ) as days influenced by "west to northeast flow (W-NE)"; and days when the net wind movement was $<120 \mathrm{~km}$ as "stagnant" or "local". From this designation, days that were affected by W-SE air transport represent days most likely influenced by polluted air masses from surrounding urban areas in Canada and the US, whereas days that were affected by W-NE air transport represent days most likely influenced by transport from remote regions. Table 1 shows the percentage of days affected by each wind designation from 2008 to 2012. Throughout this period, the summer of 2012 was affected by a relatively lower percentage of days with air transport from the W-NE and a large percentage of days experiencing stagnant periods (consistent with the previous 4 years). This could have contributed to the high $\mathrm{O}_{3}$ levels measured in the GTA in 2012, because fewer days had "clean" air transport from the north. Furthermore, Table 1 shows the percentage of exceedances at Downtown 2 affected by each wind designation, and it is evident that transport from the $\mathrm{W}$ to the SE and local/stagnant air contributes to ozone exceedances to a higher degree than transport from the $\mathrm{W}$ to the NE.

Figure 5 displays the hourly summer averages at Toronto Downtown2 for $\mathrm{O}_{3}$ from the three designated air directions, as well as from all directions. Overall, air transport from $\mathrm{W}$ to $\mathrm{SE}$ or locally produced resulted in the highest daily maximum $\mathrm{O}_{3}$ levels. Between 2010 and 2012, the inter-annual variability in the maximum daily $\mathrm{O}_{3}$ - reached when air arrived from $\mathrm{W}$ to $\mathrm{NE}$ - was much less than when air arrived from the $\mathrm{W}$ to the SE. The maximum daily $\mathrm{O}_{3}-$ reached in 2012 , when air was arriving from the $\mathrm{W}$ to the $\mathrm{SE}$ - was significantly higher than in 2010 or 2011; this occurrence helps 
Table 1. Percentage of days and exceedances (at Downtown2) each summer (2008-2012) that were affected by air transport from the W to the NE, the $\mathrm{W}$ to the SE or local/stagnant air.

\begin{tabular}{ccc|cc|cc}
\hline Year & $\begin{array}{c}\text { Days with } \\
\text { transport from }\end{array}$ & $\begin{array}{c}\text { Exceedances } \\
\text { from }\end{array}$ & $\begin{array}{c}\text { Days with } \\
\text { transport from }\end{array}$ & $\begin{array}{c}\text { Exceedances } \\
\text { from }\end{array}$ & $\begin{array}{c}\text { Days with } \\
\text { transport from }\end{array}$ & $\begin{array}{c}\text { Exceedances } \\
\text { from }\end{array}$ \\
\hline \multicolumn{2}{r}{ W-NE } & \multicolumn{2}{|c|}{ W-SE } & \multicolumn{2}{c}{ Local } \\
\hline 2008 & 29 & 0 & 18 & 17 & 52 & 83 \\
2009 & 33 & 20 & 14 & 40 & 53 & 40 \\
2010 & 29 & 0 & 26 & 33 & 45 & 66 \\
2011 & 38 & 33 & 9 & 17 & 53 & 50 \\
2012 & 25 & 6 & 20 & 29 & 54 & 65 \\
\hline
\end{tabular}

to explain the increase in $\mathrm{O}_{3}$ observed in 2012. Finally, the maximum daily $\mathrm{O}_{3}$ reached during stagnant conditions was again higher in 2012 than in 2010 or 2011. This increase in local $\mathrm{O}_{3}$ concentrations cannot be explained by wind transport or a change in precursor concentrations, as explained in Sect. 3.2, and therefore other meteorological influences must be affecting the local maximum level of $\mathrm{O}_{3}$ reached. This analysis was performed for other stations, as well as using $\mathrm{O}_{\mathrm{x}}$ concentrations, and the same general conclusions can be made.

Since the local $\mathrm{O}_{3}$ levels experienced in 2012 cannot be explained by changes in air transport or precursor concentrations, it is likely a result of changes in the photochemistry occurring in the troposphere. The level of photochemical activity occurring during each summer day was analyzed by considering the amount of incoming solar radiation in the GTA. Data collected from a net radiometer at UTMMS were analyzed for the period 2008-2012. Figure 6a displays a regression between Downtown 2 maximum $8 \mathrm{~h} \mathrm{O}_{3}$ levels (ppb) and midday incoming solar radiation (from 11:00 to 15:00, the time when $\mathrm{O}_{3}$ production is maximized, in $\mathrm{W} \mathrm{m}^{-2}$ ) in 2012. From the $R^{2}$ value, it is clear that the variance in $\mathrm{O}_{3}$ levels can partly $(\sim 16 \%)$ be explained by midday radiation levels (variances ranged from $\sim 8$ to $19 \%$ from 2008 to 2012). Based on this figure, a midday average of $\sim 600 \mathrm{~W} \mathrm{~m}^{-2}$ is required for an ozone exceedance. Figure $6 \mathrm{~b}$ shows the annual cumulative distribution function of the midday average summer solar radiation data plotted against the number of days in each summer. For the period 2008-2012, 2012 experienced the greatest number of days affected by a midday solar radiation average $>600 \mathrm{~W} \mathrm{~m}^{-2} ; 2012$ experienced 103 days of $>600 \mathrm{~W} \mathrm{~m}^{-2}$ levels of incoming solar radiation, whereas 2011 and 2010 experienced 84, 2009 experienced 92 and 2008 experienced 85 . When this analysis was performed with the pyranometer data from the UTMMS site, the same qualitative result was obtained. The amount of incoming solar radiation will strongly influence the production of $\mathrm{HO}_{\mathrm{x}}$ radicals, and thus the ability for $\mathrm{O}_{3}$ to be produced; local $\mathrm{O}_{3}$ production is minimized on "cloudy" days with lower levels of incoming solar radiation and maximized on "clear" days with medium to higher levels of incoming solar radiation.

\subsection{VOC- or $\mathrm{NO}_{\mathrm{x}}$ limited ozone production}

The ozone production regime is dictated by the fate of $\mathrm{HO}_{\mathrm{x}}$ radicals, whether the $\mathrm{RO}_{2}$ radical self-reacts (denoting a $\mathrm{NO}_{\mathrm{x}}$-sensitive regime) or the $\mathrm{OH}$ radical reacts with $\mathrm{NO}_{2}$ to form $\mathrm{HNO}_{3}$ (denoting a VOC-sensitive regime) (Reactions R8 and R9). Based on the data available, we used the relative reactivity of $\mathrm{OH}$ to $\mathrm{NO}_{2}$ and the sum of 40 speciated NAPS VOCs at the Downtown sites as an approach to approximate the ozone production regime during the study period. Figure 7 shows $\mathrm{OH}$ reactivity to each species in "early" (2002-2003) and "late" (2011-2012) periods of the data set. In the early period, $\mathrm{NO}_{2}$ accounted for a larger portion of $\mathrm{OH}$ reactivity relative to VOCs, 4.93 and $3.64 \mathrm{~s}^{-1}$, respectively. In the late period, although reactivity toward both compounds decreased, $\mathrm{NO}_{2}$ reactivity to $\mathrm{OH}$ accounts for an increasingly larger portion of total reactivity; 2.88 vs. $1.68 \mathrm{~s}^{-1}$ for VOC reactivity. When these calculations were performed using data from the suburban Brampton site, $\mathrm{NO}_{2}$ was also found to account for a larger proportion of $\mathrm{OH}$ reactivity. There are limited long-term CO measurements in the GTA during this period. However, data from the Toronto West 2 station suggests that midday reactivity with $\mathrm{CO}$ decreased from 1.4 to $0.77 \mathrm{~s}^{-1}$ between 2003 and 2012. These results suggest that the preferred fate of $\mathrm{OH}$ radical in the late period is in reaction with $\mathrm{NO}_{2}$ (Reaction R9), thereby suggesting that ozone production has become more $\mathrm{NO}_{\mathrm{x}}-$ saturated and more sensitive to VOC reactivity over the last decade. Similar to the study by Geddes et al. (2009), when we use a simple analytical model to generate a contour plot of instantaneous ozone production as a function of VOC reactivity and $\mathrm{NO}_{2}$ concentrations, plotting the data from GTA surface monitoring stations also suggests that the region is in a VOC-limited regime.

This analysis of the GTA ozone production regime is limited because the ambient concentrations of $\mathrm{NO}_{\mathrm{x}}$ and VOCs were made at sites near the ground, whereas ozone formation takes place in a convective layer which can extend hundreds of meters above the surface (Sillman, 1999). Surface observations likely overestimate the average concentration of primary pollutants within the boundary layer, especially 

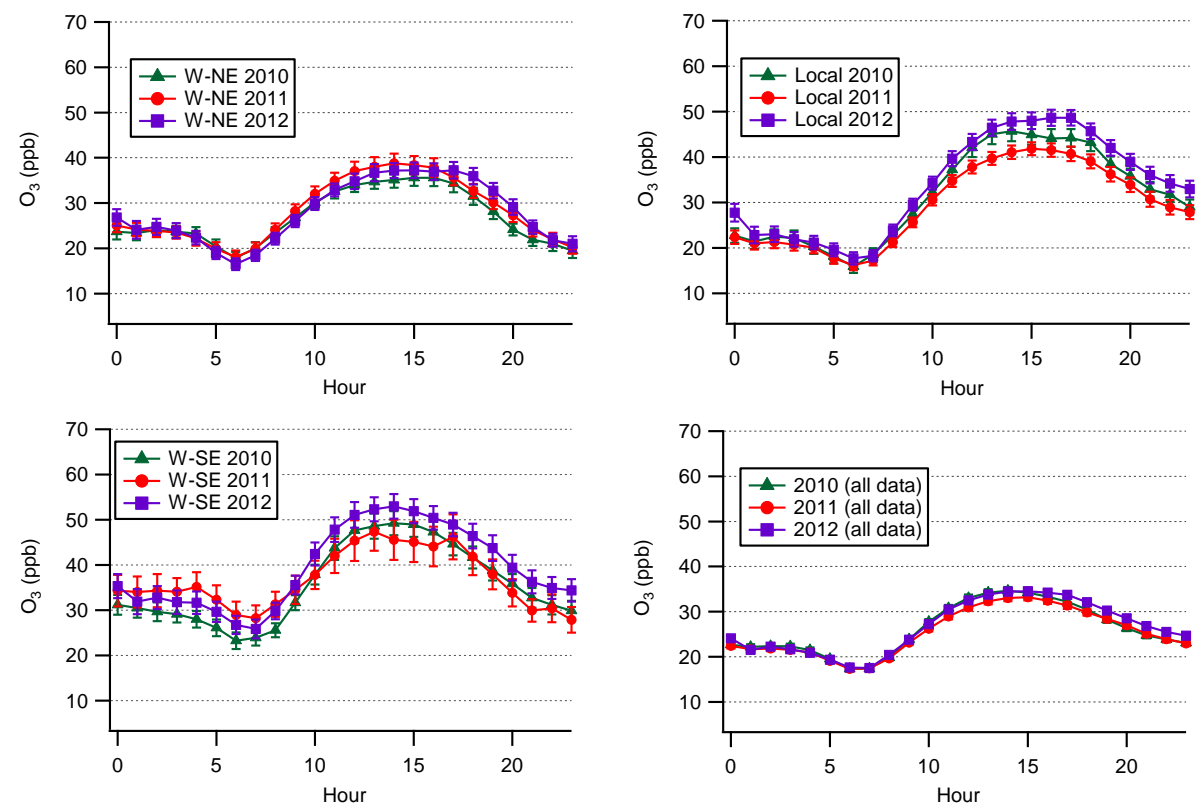

Figure 5. $\mathrm{O}_{3}$ hourly summer averages at Downtown2 Toronto station (error bars represent standard deviation of the mean).
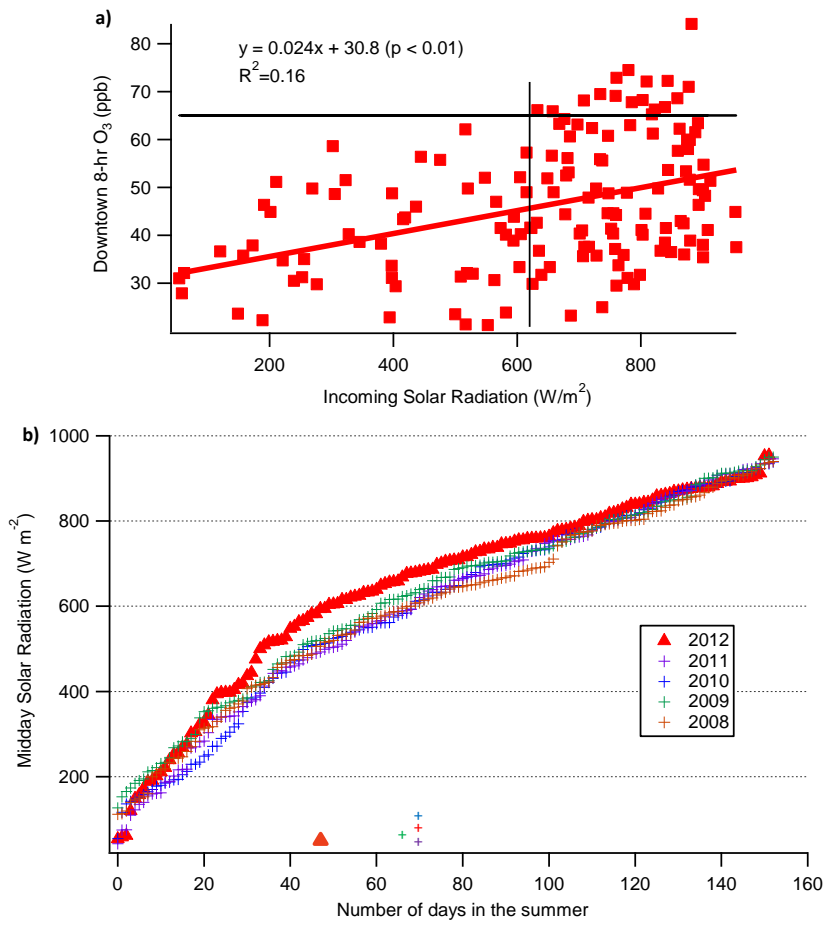

Figure 6. (a) Regression of Downtown $28 \mathrm{~h} \mathrm{O}_{3}$ versus incoming solar radiation $\left(\mathrm{W} \mathrm{m}^{-2}\right)$ for 2012 (black lines are the thresholds of incoming solar radiation where $65 \mathrm{ppb}$ of $\mathrm{O}_{3}$ is exceeded); (b) Cumulative distributions of the midday average solar radiation $\left(\mathrm{W} \mathrm{m}^{-2}\right)$ experienced on each summer day (2008-2012) (markers above the $x$ axis are provided to easily identify the difference in the number of days exceeding $600 \mathrm{~W} \mathrm{~m}^{-2}$ for 2012 and the previous four years). for shorter-lived compounds. Another limitation to the VOC analyses performed in this study is the exclusion of OVOCs from all monitoring stations except Junction. In 2011, we performed 5 separate days of $3 \mathrm{~h}$ canister measurements during a 2-week period between 27 August and 12 September. The $\mathrm{OH}$ reactivity to non-methane hydrocarbons was calculated as two fractions: VOCs (the same 40 VOCs as chosen from Environment Canada data, with the exception of propylene and isopentane) and OVOCs ( 23 compounds). Throughout the 2-week period, the OVOCs accounted for $\sim 60 \%$ of the total $\mathrm{OH}$ reactivity to VOCs. It is possible, however, that this may be an overestimate of midday $\mathrm{OH}$ reactivity; for the 2-week sampling period, the average $24 \mathrm{~h}$ VOC reactivity from the traditional NAPS compounds was $1.6 \mathrm{~s}^{-1}$ and from the OVOC compounds was $2.4 \mathrm{~s}^{-1}$. Focusing only on samples collected between 12:00 and 15:00, the reactivity from the traditional NAPS compounds was $1.3 \mathrm{~s}^{-1}$ and from the OVOC compounds was $2.3 \mathrm{~s}^{-1}$. Therefore, based on this limited set of more detailed measurements, we can infer that $24 \mathrm{~h}$ average NAPS samples may overestimate the midday reactivity from the traditional compounds by $19 \%$ and the total VOC reactivity (VOC + OVOCs) by $10 \%$. These detailed measurements also suggest that ozone production may be more $\mathrm{NO}_{\mathrm{x}}$-sensitive than was determined using the traditional VOC measurements. Overall, these results suggest that our current understanding of VOC reactivity in the GTA is incomplete.

\subsection{GTA OH radical concentration}

Since the $\mathrm{OH}$ radical plays a key role in the production of ozone, it is important to understand how its abundance in 


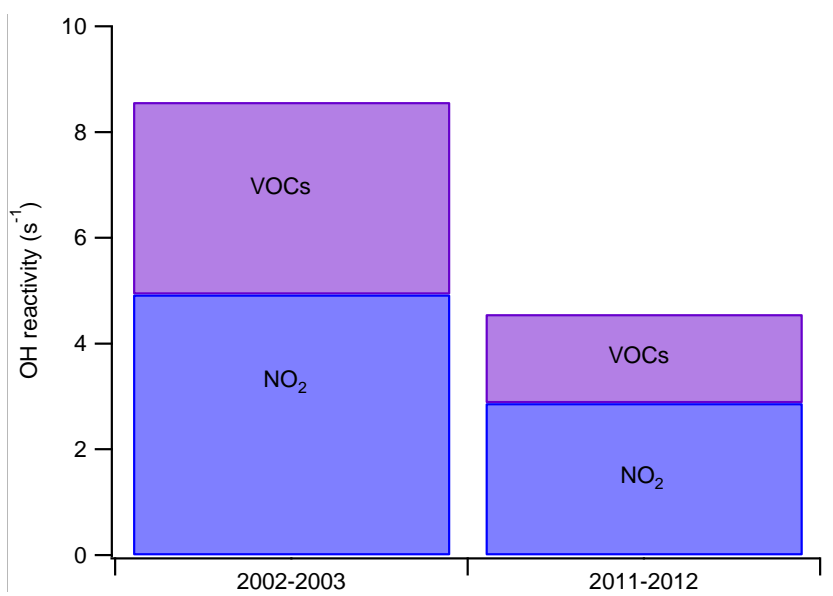

Figure 7. $\mathrm{OH}$ reactivity $\left(\mathrm{s}^{-1}\right)$ to $\mathrm{NO}_{2}$ and NAPS VOCs in the "early" period (2002-2003) and "late" period (2011-2012) at the Downtown sites.

the GTA has changed over the study period. By monitoring the ratio of two co-emitted VOCs, we can estimate how the concentration of $\mathrm{OH}$ has changed, assuming the distribution of distances from the emission sources to the receptor (monitoring site) has not changed. Figure 8 displays the ratio of two alkenes, 1-butene $\left(k_{\mathrm{OH}}=3.0 \times 10^{-11} \mathrm{~cm}^{3} \mathrm{molec}^{-1} \mathrm{~s}^{-1}\right)$ and cis-2-butene $\left(k_{\mathrm{OH}}=5.6 \times 10^{-11} \mathrm{~cm}^{3} \mathrm{molec}^{-1} \mathrm{~s}^{-1}\right)$, as well as two aromatic VOCs, 1,2,3-trimethylbenzene $\left(k_{\mathrm{OH}}=3.3 \times 10^{-11} \mathrm{~cm}^{3} \mathrm{molec}^{-1} \mathrm{~s}^{-1}\right) \quad$ and ethylbenzene $\left(k_{\mathrm{OH}}=7.1 \times 10^{-11} \mathrm{~cm}^{3} \mathrm{molec}^{-1} \mathrm{~s}^{-1}\right)$. All of these compounds have lifetimes in the atmosphere on the order of a few hours, assuming an $\mathrm{OH}$ concentration of $10^{6} \mathrm{molec}^{-3}$, and therefore observations made in downtown Toronto should predominantly reflect oxidation rates in the GTA atmosphere. We assume that the emission ratios of these compound pairs have not changed substantially during the study period. Additionally, with $\mathrm{O}_{3}$ levels changing minimally during the study period, we assume that the oxidation of these compounds from $\mathrm{O}_{3}$ has not changed significantly during this time. As Fig. 8 displays, the ratio for each pair of compounds is smaller in the early period than in the late period, with medians changing from 3.5 to 4.5 for 1-butene : 2-butene and 0.19 to 0.25 for 1,2,3-trimethylbenzene: ethylbenzene. Since cis-2-butene and ethylbenzene have higher rates of reaction with $\mathrm{OH}$ with respect to their paired VOC, this increase in their ratio indicates that the $\mathrm{OH}$ concentration in the GTA has increased from the early to late period. Assuming that the rates of $\mathrm{HO}_{\mathrm{x}}$ production have stayed relatively constant, higher levels of $\mathrm{OH}$ in 2011-2012 are consistent with the large reduction in total reactivity, described in Sect. 3.4. An increase in $\mathrm{OH}$ radical abundance has implications for ozone production, the relationship between precursor emissions and concentrations, and the oxidative capacity of the troposphere. a)

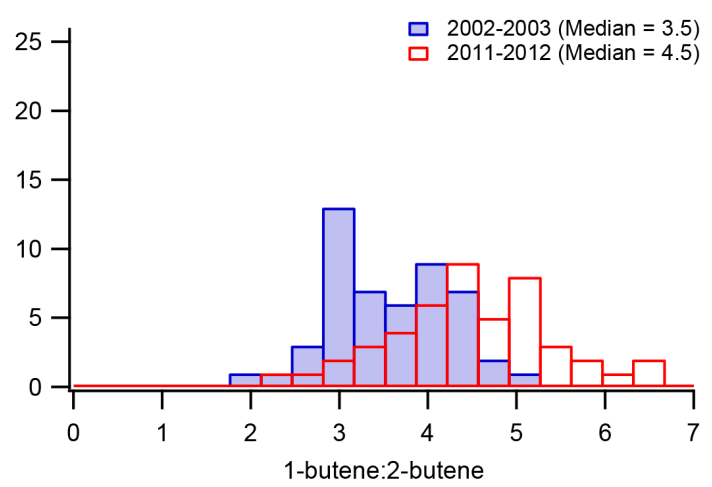

b)

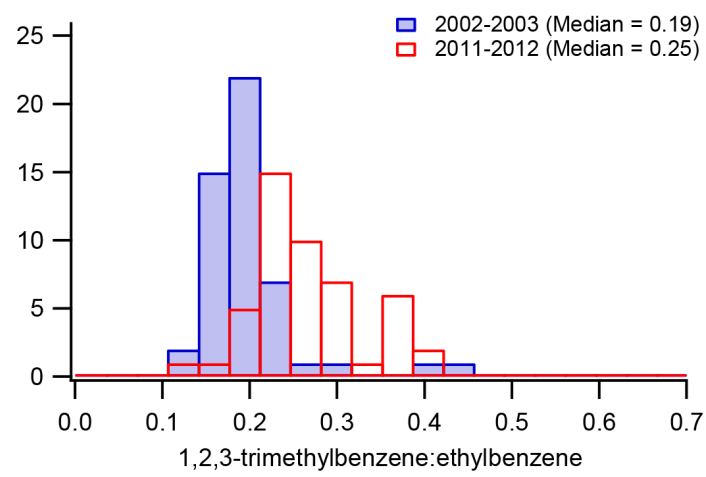

Figure 8. Histograms of 1-butene:2-butene (a) and 1,2,3trimethylbenzene : ethylbenzene (b) in the early (2002-2003) and late (2011-2012) periods.

\subsection{Assessing the success of the Climate Change, Clean Air and Sustainable Energy Action Plan}

In 2007, the City of Toronto made a commitment to reduce emissions of local smog-causing pollutants $20 \%$ below 2004 levels by 2012. Table 2 shows the percentage differences between 2004 and $2012 \mathrm{NO}_{2}$ and VOC concentrations at all sites monitored (using the original suite of 40 NAPS VOC compounds). Reductions in $\mathrm{NO}_{2}$ concentrations ranged from 27.4 to $49.9 \%$ (Toronto North and Brampton2, respectively), providing evidence of the success of the implemented mitigation strategies during the past decade, such as catalytic converters on vehicles and new combustion technology to reduce $\mathrm{NO}_{\mathrm{x}}$ emissions from power plants (ICF, 2007). Additionally, reductions in VOC concentrations ranged from 31.7 to $52.8 \%$ (Downtown 1 and West1, respectively). Again, this result provides support for the success of the City of Toronto strategies aimed at reducing anthropogenic emissions of these compounds, such as the ChemTRAC initiative, which includes a focus on reducing the VOC content in paints and wood coatings (Toronto Public Health, 2013). While these results suggest that the emission reduction target may have been achieved, there are limitations to our interpretation of the data. Monitoring network data suggests that the concentrations of $\mathrm{NO}_{2}$ and VOCs have been reduced by more 
Table 2. The percentage difference between 2004 and $2012 \mathrm{NO}_{2}$ and VOC concentrations (ppb) at all stations monitored (Junction was not included as monitoring stopped in 2005).

\begin{tabular}{lcccccccc}
\hline Station & Downtown & North & East & West & Oshawa & Brampton & Newmarket & Oakville \\
\hline $\mathrm{NO}_{2}(\%)$ & 31.2 & 27.4 & 29.1 & 42.1 & 34.6 & 49.9 & 26.8 & 30.3 \\
$\mathrm{VOC}(\%)$ & 31.7 & - & - & 52.8 & - & 33.4 & - & - \\
\hline
\end{tabular}

than $20 \%$, but the action plan commitments are actually for emissions. In Sect. 3.4, we showed that oxidation rates in the urban atmosphere appear to have accelerated, meaning that changes in emissions and concentrations will have a nonlinear relationship, and that the data in Table 2 likely overestimate the changes in emissions. Nevertheless, the large reduction in concentrations is likely consistent with a decrease of more than $20 \%$ in emissions, though exact quantification is difficult. Furthermore, as suggested in Sect. 3.3, the role of OVOCs as ozone precursors in the GTA is unclear due to lack of monitoring, and therefore these conclusions about the success of the action plan are not necessarily comprehensive.

\section{Conclusions}

Significant reductions in the summertime mean daily concentrations of $\mathrm{O}_{3}$ precursor compounds have been observed since 2000; $\mathrm{NO}_{2}$ levels decreased by $-6.4 \%$ per year in urban sites and $-5.8 \%$ per year in suburban sites, and VOC reactivity decreased by at least $-9.3 \%$ per year. These results provide evidence for the effectiveness of implemented vehicle emission clean-up technologies, as well as other regulatory initiatives throughout the province and municipalities in the GTA. In response to these decreases, GTA $\mathrm{O}_{3}$ levels have also decreased about $-0.4 \%$ per year at urban sites and $-1.1 \%$ per year at suburban sites during the 13-year study period. In 2012, however, some of the highest recorded $\mathrm{O}_{3}$ concentrations were observed following 4 years of consistently low levels. Since concentrations of both precursor compounds have continued decreasing since 2008 , this increase must have been influenced by the meteorology experienced in 2012. We found that, although the warm temperatures experienced in 2012 did not likely play a role in the $\mathrm{O}_{3}$ increase compared to 2010 and 2011, air transport from upwind regions may have. Compared to the preceding 4 years, the summer of 2012 was affected by a large percentage of days with air transport from the $\mathrm{W}$ to the SE (polluted air traveling over urban areas in Canada and the US), a small percentage of days with air transport from the $\mathrm{W}$ to the NE (clean air traveling over remote regions) and a large percentage of days affected by stagnant conditions (air trapped over the GTA allowing precursor compounds to accumulate and enhance local $\mathrm{O}_{3}$ production). Additionally, since the production of $\mathrm{O}_{3}$ depends on photochemistry in the troposphere, the levels of incoming solar radiation were analyzed during the study period. It was found that 2012 experienced the largest number of days with midday levels of incoming solar radiation exceeding $600 \mathrm{~W} \mathrm{~m}^{-2}$, which likely contributed to the enhancement of local $\mathrm{O}_{3}$ production.

The results of this study also demonstrate the success of the GTA in achieving the $20 \%$ reduction in precursor emissions set by the Toronto Climate Change, Clean Air and Sustainable Energy Action Plan in 2007. Between 2004 and 2012, $\mathrm{NO}_{2}$ reductions ranged from 27.4 to $49.9 \%$, and VOC concentration reductions ranged from 31.7 to $52.8 \%$. These results provide evidence of the benefits of municipal and provincial regulations aimed at controlling the emission of ozone precursors throughout the past decade. Nevertheless, the ozone design value at all GTA monitoring stations has exceeded the Canada-wide Standard every year between 2002 and 2012. Reductions in precursor emissions appear to have increased in the local abundance of $\mathrm{OH}$, resulting in only moderate reductions in local ozone production rates. The importance of including OVOCs in $\mathrm{O}_{3}$ production analyses has been demonstrated, as short-term measurements indicate that they account for a significant fraction of $\mathrm{OH}$ reactivity.

Acknowledgements. The authors are grateful to Environment Canada's NAPS (National Air Pollutant Surveillance) for the VOC data used in this study. Additionally, the authors are thankful to the Environmental Monitoring and Reporting Branch at the Ontario Ministry of the Environment for providing hourly $\mathrm{O}_{3}$ and $\mathrm{NO}_{\mathrm{x}}$ data, as well as to the UTMMS for providing hourly incoming solar radiation data.

Edited by: L. Zhang

\section{References}

Agudelo-Castaneda, D., Teixeira, E., Rolim, S., Pereira, F., and Wiegand, F.: Measurement of Particle Number and Related Pollutant Concentrations in an Urban Area in South Brazil, Atmos. Environ., 70, 254-262, 2013.

Atkinson, R.: Gas-Phase Tropospheric Chemistry of Volatile Organic Compounds. 1. Alkanes and Alkenes, J. Phys. Chem. Ref. Data, 26, 215-290, 1997.

Baertsch-Ritter, N., Keller, J., Dommen, J., and Prevot, A. S. H.: Effects of various meteorological conditions and spatial emissionresolutions on the ozone concentration and ROG/NO $\mathrm{Nim}$ itationin the Milan area (I), Atmos. Chem. Phys., 4, 423-438, doi:10.5194/acp-4-423-2004, 2004.

Bell, M. L., Samet, J. M., and Dominici, F.: Ozone and mortality: A meta-analysis of time-series studies and comparison to a 
multi-city study (the national morbidity, mortality, and air pollution study), availabe at: http://biostats.bepress.com/jhubiostat/ paper57 (last access: 18 November 2013), 2004.

Bell, M. L., Dominici, F., and Samet, J. M.: A Meta-Analysis of Time-Series Studies of Ozone and Mortality with Comparison to the National Morbidity, Mortality and Air-Pollution Study, Epidimiology, 16, 436-445, 2005.

Bradley, H. J. J.: Bill 138, ending coal for cleaner air act, available at: http://www.ontla.on.ca/web/bills/bills_detail.do?locale= en\&Intranet\&BillID=2901 (last access: 5 March 2014), 2013.

Camalier, L., Cox, W., and Dolwick, P.: The Effects of Meteorology on Ozone in Urban Areas and their use in Assessing Ozone Trends, Atmos. Environ., 41, 7127-7137, 2007.

City of Toronto: Climate change, clean air and sustainable energy action plan: Moving from framework to action, available at: http://www.toronto.ca/legdocs/mmis/2007/pe/bgrd/ backgroundfile-4982.pdf (last access: 14 December 2013), 2007.

Dawson, J. P., Adams, P. J., and Pandis, S. N.: Sensitivity of Ozone to Summertime Climate in the Eastern USA: A Modeling Case Study, Atmos. Environ., 41, 1494-1511, 2007.

Environment Canada: Canada wide standards (CWS), available at: http://www.ec.gc.ca/rnspa-naps/default.asp?lang=En\&n= 07BC2AC0-1, last access: 19 December 2013.

Farmer, D. K., Perring, A. E., Wooldridge, P. J., Blake, D. R., Baker, A., Meinardi, S., Huey, L. G., Tanner, D., Vargas, O., and Cohen, R. C.: Impact of organic nitrates on urban ozone production, Atmos. Chem. Phys., 11, 4085-4094, doi:10.5194/acp-11-40852011, 2011.

Figueiredo, M., Monteiro, A., Lopes, M., Ferreira, J., and Borrego, C.: Air Quality Assessment of Estarreja, an Urban Industrialized Area, in a Coastal Region of Portugal, Environ. Monit. Assess., 185, 5847-5860, 2013.

Geddes, J., Murphy, J., and Wang, D.: Long Term Changes in Nitrogen Oxides and Volatile Organic Compounds in Toronto and the Challenges Facing Local Ozone Control, Atmos. Environ., 43, 3407-3415, 2009.

ICF: Greenhouse gases and air pollutants in the city of Toronto: Towards a harmonized strategy for reducing emissions, available at: http://www1.toronto.ca/city_of_toronto/environment_and_ energy/key_priorities/files/pdf/ghg-aq-inventory-june2007.pdf (last access: 13 August 2013), 2007.

Jacob, D., Logan, J., Gardner, G., Yevich, R., Spivakovsky, C., and Wofky, S.: Factors Regulating Ozone over the United States and its Export to the Global Atmosphere, J. Geophys. Res., 98, 14817-14826, 1993.

Makar, P. A., Zhang, J., Gong, W., Stroud, C., Sills, D., Hayden, K. L., Brook, J., Levy, I., Mihele, C., Moran, M. D., Tarasick, D. W., He, H., and Plummer, D.: Mass tracking for chemical analysis: the causes of ozone formation in southern Ontario during BAQS-Met 2007, Atmos. Chem. Phys., 10, 11151-11173, doi:10.5194/acp-10-11151-2010, 2010.

MOE: Transboundary air pollution in Ontario, Ontario Ministry of the Environment, http://www.ene.gov.on.ca/stdprodconsume/ groups/lr/@ene/@ resources/documents/resource/std01_079137. pdf (last access: 6 September 2013), 2005.
MOE: Drive clean, http://www.ene.gov.on.ca/environment/en/ category/drive_clean/index.htm (last access: 5 March 2014), 2013.

MOE: Smog advisory statistics, http://www.airqualityontario.com/ press/smog_advisories.php, last access: 11 June 2014.

Oltmans, S. J., Lefohn, A. S., Shadwick, D., Harris, J. M., Scheel, H. E., Galbally, I., Tarasick, D. W., Johnson, B. J., Brunke, E. G., Claude, H., Zeng, G., Nichol, S., Schmidlin, F., Davies, J., Cuevas, E., Redondas, A., Naoe, H., Nakano, T., and Kawasato, T.: Recent Tropospheric Ozone Changes - A Pattern Dominated by Slow or no Growth, Atmos. Environ., 67, 331-351, 2013.

Pekey, B. and Ozaslan, U.: Spatial Distribution of $\mathrm{SO}_{2}, \mathrm{NO}_{2}$ and $\mathrm{O}_{3}$ Concentrations in an Industrial City of Turkey using a Passive Sampling Method, Clean-Soil Air Water, 41, 423-428, 2013.

Perring, A. E., Bertram, T. H., Farmer, D. K., Wooldridge, P. J., Dibb, J., Blake, N. J., Blake, D. R., Singh, H. B., Fuelberg, H., Diskin, G., Sachse, G., and Cohen, R. C.: The production and persistence of $\Sigma \mathrm{RONO}_{2}$ in the Mexico City plume, Atmos. Chem. Phys., 10, 7215-7229, doi:10.5194/acp-10-72152010, 2010.

Psiloglou, B., Larissi, I., Petrakis, M., Paliatsos, A., Antoniou, A., and Viras, L.: Case Studies on Summertime Measurements of $\mathrm{O}_{3}, \mathrm{NO}_{2}$, and $\mathrm{SO}_{2}$ with a DOAS System in an Urban SemiIndustrial Region in Athens, Greece, Environ. Monit. Assess., 185, 7763-7774, 2013.

Seinfeld, J. and Pandis, S.: Atmospheric chemistry and physics: From air pollution to climate change, New Jersey: John Wiley \& Sons Inc., 2006.

Sillman, S.: The Relation between Ozone, $\mathrm{NO}_{\mathrm{x}}$ and Hydrocarbons in Urban and Polluted Rural Environments, Atmos. Environ., 33 , 1821-1845, 1999.

Sills, D. M. L., Brook, J. R., Levy, I., Makar, P. A., Zhang, J., and Taylor, P. A.: Lake breezes in the southern Great Lakes region and their influence during BAQS-Met 2007, Atmos. Chem. Phys., 11, 7955-7973, doi:10.5194/acp-11-7955-2011, 2011.

Statistics Canada: Table405-0004 - road motor vehicles, registrations, annual (number), CANSIM (database), http://www.statcan.gc.ca/tables-tableaux/sum-som/101/cst01/ trade14a-eng.htm (last access: 14 August 2013), 2011.

Statistics Canada: Focus on geography series, 2011 census, Statistics Canada catalogue no. 98-310-XWE2011004, available at: https://www12.statcan.gc.ca/census-recensement/2011/as-sa/ fogs-spg/Facts-cma-eng.cfm?LANG=Eng\&GK=CMA\&GC= 535 (last access: 13 August 2013), 2012.

Toronto Public Health: Tracking and reducing chemicals in Toronto: ChemTRAC annual report - 2011 reporting year, available at: http://www.toronto.ca/legdocs/mmis/2013/hl/bgrd/ backgroundfile-59180.pdf, last access: 19 December 2013.

Toronto Public Health: Path to healthier air: Toronto air pollution burden of illness update, avalabile at: http://www.toronto. ca/health/reports, last access: 22 January 2014.

Wang, D., Fuentes, J., Travers, D., Dann, T., and Connolly, T.: Non-Methane Hydrocarbons and Carbonyls in the Lower Fraser Valley during PACIFIC 2001, Atmos. Environ., 39, 5261-5272, 2005. 